\title{
YOUTH'S PERCEPTIONS OF INNOVATION START-UP BUSINESS
}

\section{Dr. Le Nguyen Doan Khoi}

\section{Assoc. Prof., Department Of Scientific Research Affairs, Can Tho University}

\section{ABSTRACT}

This paper focuses on youth's decision process to become innovation entrepreneurs. The first part of the paper delivers the problem statement and a literature review of latest (empirical) contributions in the field of entrepreneurship. The present survey indicated the view of the potential entrepreneurs as well as already successful youth's entrepreneurs - indicating suitable attempts for possibilities of improvement. In addition, it was useful to track youth's entrepreneurship along the enterprise life-cycle to reveal specific strengths and weaknesses in specific phases of enterprise development.

KEYWORDS : Innovation Start-up, Youth's Entrepreneurs, Entrepreneurship

\section{INTRODUCTION}

In the globalization phase, changed conditions in the job market are discussed which are connected, above all, to measure youth's labour force participation rate. Nevertheless, meanwhile the quality of concluded education and professional training of youth's entrepreneurs is on average better than that of young men. In the future this fact could also make a rise of the youth's rate in top positions more likely (Baumon, 1990). Besides, during the last years the share of women has clearly increased, above all, in the lower and middle management enabling them a career on top management levels (Neuberger, 2002).

The conditions on labour markets, particularly the youth employment rates are affected by huge changes in economic structures, e.g. globalisation, work-time flexibility but also social trends like single households, and the role and forms of entrepreneurship (Moore and Buttner, 1997). Especially the role of youth entrepreneurship as driving force of economic growth and development increased significantly. This fact presumes an increase of the youth employment rate in leading positions but also an increase of young entrepreneurship (Carter and Cannon, 1992).

\section{LITERATURE REVIEW}

In literature motives are summarised in two different categories. This is based on Gilad's and Levine's (1986) developed explanation attempts which deliver two very similar theories of entrepreneurial motivations (Segal et al., in 2005). On the one hand there are the so-called 'pull' factors which show positive incentives for the step into independence (e.g., a higher income). In contrast the 'push' factors exists which force individuals, due to negative external effects, to overcome the negative situation when founding a business. These factors are, for example, dissatisfaction with the occupation, unemployment, and insufficient payment during employment or too rigid working hours (Segal, et al., 2005).

\subsection{INDEPENDENCE MOTIVES}

The striving for independence is looked at as the most important 'pull' factor for independence. Carter and Cannon (1992) divide the motivation of independence into four different groups including (1) aspirants; (2) high achievers; (3) re-entrants; (4) traditionalists

These different forms of motives and the grouping of youth entrepreneurs resulting from it, is of course not lasting, because entrepreneurship takes also strong flexibility for being successful in the long run.

\subsection{ECONOMIC MOTIVES}

Baumol (1990) analyzed the factors 'necessity', 'usability' and 'desirability' of an entrepreneurial career. Praag and Cramer (2001) assumed that somebody will decide on independency when the expected remuneration of the independent activity exceeds the one being employed. Besides, entrepreneurial activity consists of the factors feasibility and desirability. Accordingly Levesque et al. (2002) also dealt with a use maximising model that analyzes the decision between independent and dependent work, whereby this often changes depending on the age of the individual (Segal et al., 2005).

\subsection{PERSONAL MOTIVES}

Besides striving for independence and economical goals even other motives are imaginable which mostly originate from personal experience leading therefore to the final decision for independence. These kinds of motives can be seen as 'push' as well as 'pull' factors (Gartner et al., 2000).

Results from earlier studies are summarised in the following table which especially analyzed the motives of youth's entrepreneurs. The most often identified main factors are compatibility of job and family (Lundstrom, 1999; Caputo and Dolinsky, 1998, Marlow and Strange, 1994; Birley 1989), independence (Sacirbey, 1998), autonomy (Kleinman, 1998; McKay, 2001), overcoming discontent with work (Babaeva and Chirikova, 1997; Oeltjen, 1992) and loss of the workplace (Sacirbey, 1998; Babaeva and Chirikova, 1997).

\section{METHODOLOGY}

We used interview methodology for our study. The interviews have been carried out during spring and summer 2018. The average duration of an interview was 60 minutes. The interview questionnaire based on the results of a quantitative evaluation in which 150start-up business and 120 students from economic faculty were asked about their entrepreneurial attitude. The aim of the overall project was to assess differences between youth's expectations about entrepre neurship and young's evaluations of their entrepreneurial activity. Therefore, the qualitative interviews attempted to asses motivators of youth entrepreneurship, perceived difficulties during their entrepreneurial activities.

\section{RESEARCH RESULTS}

The interviewees most often called the motive of continuation of family tradition as most decisive for becoming an entrepreneur. Nevertheless, this seems to be a motive which is relatively superficial, on account of the small scaled business. Motives, such as independence and self-realization were named in each case as a determining motive for independent employment by two entrepreneurs. These two motives have also been determined as essential in international studies over and over again (McKay, 2001). 
'Being a staff leader' as well as 'having fun at work' was mentioned only once as a decisive reason in each case for considering an entrepreneurial activity. Surprisingly the possibility to combine job and family likewise was also only important for one of the young entrepreneurs.

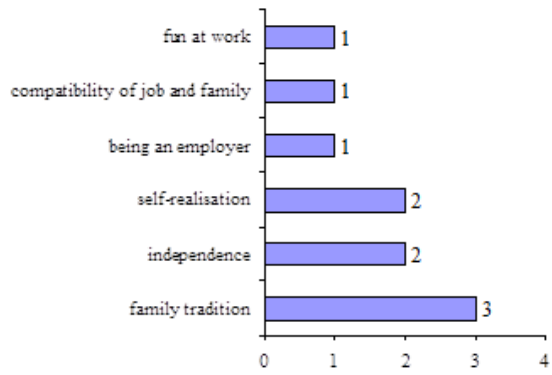

Figure 1: Motivators for the start of independent empl oyment

Even if the compatibility of job and family was no reason for the questioned female entrepreneurs to become independent, the double load was called as essentially difficult by at least three youth entrepreneurs.

The reason why of the big dispersion within the named difficulties individual circumstances seem to be very decisive for the appearing problems. For example, a high time expenditure, prize competition as well as tax and finance problems or the procurement of capital can be counted to it. Merely one female entrepreneur represented the view that no difficulties appear with independent employment.

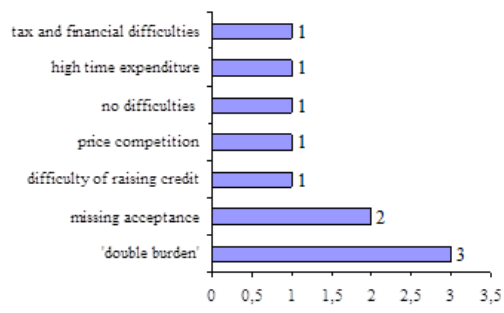

Figure 2: Difficulties of a young's entrepreneur

Following that, similarly to the quantitative questionings also the results of the single case studies are briefly summarised in tabular form. The results refer to those answers which were stated by the majority of the interviewed youth entrepreneurs and to average values.

Table 1: Summary of results from surveys

\begin{tabular}{|c|c|}
\hline Variables & Youth entrepreneurs \\
\hline time of business foundation & with $\sim 20$ years \\
\hline $\begin{array}{l}\text { form/Type of business } \\
\text { foundation }\end{array}$ & sole business foundation \\
\hline legal form & single enterprise \\
\hline business size & smallest or small enterprise \\
\hline $\begin{array}{l}\text { motivators for } \\
\text { entrepreneurship }\end{array}$ & continue family tradition \\
\hline $\begin{array}{l}\text { difficulties during business } \\
\text { foundation }\end{array}$ & double load \\
\hline $\begin{array}{l}\text { differences between female } \\
\text { and male entrepreneurs }\end{array}$ & $\begin{array}{l}\text { only achievement counts, but } \\
\text { perhaps difficulties in some } \\
\text { branches for women or due to } \\
\text { double load }\end{array}$ \\
\hline family status & married \\
\hline children & yes, partially already grown up \\
\hline highest level of education & $\begin{array}{l}\text { finished apprenticeship } \\
\text { (+master's certificate) }\end{array}$ \\
\hline
\end{tabular}

\begin{tabular}{|l|l|}
\hline financing & $\begin{array}{l}\text { primarily and exclusively } \\
\text { with privately owned capital }\end{array}$ \\
\hline changes & $\begin{array}{l}\text { would do it again essentially } \\
\text { the same way and become } \\
\text { an entrepreneur }\end{array}$ \\
\hline
\end{tabular}

\section{CONCLUSIONS}

In summary, we found a positive trend is to be recognised from that point of view that in the future will be more successful youth entrepreneurs. A strong need for action is obviously still necessary to reach similar equalization also in the area of young entrepreneurs (at least numerical) as it can be registered with employees. Therefore, measures would have to be taken at the different levels; on the one hand at political level to create suitable juridical basic conditions for still necessary support measures e.g. in the area of child care. In this area, above all, the initiative of parents, educators and different training centres is required, to cause necessary changes especially within the younger generation.

\section{REFERENCES}

1. Baumol, W.J. (1990). Entrepreneurship. Productive, unproductive, and destructive. Journal of Political Economy, 98, 893-921

2. Gilad, B., Levine, P. (1986). A behavioral model of entrepreneurial supply. Journal of Small Business Management, 24(4), 45-53

3. Moore, D. P., Buttner, E. H. (1997) Women entrepreneurs. Moving beyond the glass ceiling. Thousand Oaks, Sage

4. Neuberger, O. (2002) Führen und führen lassen. Stuttgart: Lucius \& Lucius

5. Poza, E. J., Messer, T. (2001). Spousal Leadership and Continuity in the Family Firm. Family Business Review, 14(1), 25-36

6. Segal, G., Borgia, D., Schoenfeld, J. (2005). The motivation to become an entrepreneur. International Journal of Entrepreneurial Behaviour \& Research $11(1), 42-57$

7. Srinivasan, R., Woo, C. Y., Cooper, A. C. (1994). Performance determinants for male and female entrepreneurs. Frontiers of Entrepreneurship Research, 1994 Edition.

8. Verheul, I., Uhlaner, L., Thurik, R. (2005). Business accomplishments, gender and entrepreneurial self-image. Journal of Business Venturing, 20(4), 483-518

9. Wirth, L. (2004). Breaking through the glass ceiling. Women in management. Geneva, International Labour Office. 